\title{
YUNUS EMRE
}

VE DÜNYA DiLi TÜRKÇE YILI

\section{Yunus Emre Döneminde Anadolu'nun İktisadi Çöküşü ve Vergi Zulmü ${ }^{1}$}

\author{
Burak ÖKDE 2
}

\section{Öz}

Yunus Emre Türk Dünyası'nın yetiştirmiş olduğu saygın şair ve düşünce insanlarından biridir. Yetiştiği dönemin zor şartlarına rağmen hoşgörü ve barış dilini şiirlerinde temel alan bir üslup belirlemiştir. Bu üslup onu yüzyllar boyunca hatırlanan ve saygı gören bir isim hâline getirmiştir. Özellikle yaşadığı dönem göz önüne alındığında Yunus'un dili daha çok takdir görmektedir. 13. yüzyılda Anadolu tarihte örneği az rastlanır bir değişim yaşamıştır. Bu yüzyılın ilk yarısı bolluk, refah ve huzur dönemi olmuştur. Yunus'un yaşadığı ikinci yarısı ise savaşlar, isyanlar, yağmalar ve Moğol baskısı ile geçen, can ve mal güvenliğinin olmadığı bir dönemdir. Çalışmanın amacı da 13. yüzyılın ikinci yarısında ve 14. yüzyılın başlarında yani Yunus'un yaşadı̆̆ı dönemde, Anadolu'da meydana gelen iktisadi ve ticari hayatın değişimi ortaya koymaktır. Çalışma sonucunda Anadolu'da halk üzerinde yoğun bir vergi yükünün olduğu, huzur ve refahın yerini sefalet ve savaşların aldı̆̆ı ve iktisadi hayatın sistemsel olarak çöktüğü ortaya koyulmaktadır. Ortaya çıkan yeni durum Anadolu'da büyük göçlerin yaşanmasına, batı bölgelerinde yer alan uç beyliklerinin nüfusunun artmasına neden olmuştur. Beyliklerin doğu tarafından Moğol baskısı ve işgali ile kuşatıldıklarını göz önüne alırsak, Türkler’in batıya doğru olan fetih ve yerleşme politikaların da daha iyi anlayabiliriz. Devlet otoritesinin olmadı̆̆ı, yokluk, kıtlık, savaş, yağma ve isyanların olduğu bir dönemde, Yunus'un sevgi ve hoşgörü yaklaşımı, O’nu daha değerli kılmaktadır.

Anahtar Kelimeler: Yunus Emre, Anadalu Selçuklu Devleti, Vergi, Vergi Baskısı

Atıf: Ökde, B. (2022). Yunus Emre döneminde Anadolu’nun iktisadi çöküşü ve vergi zulmü. Anadolu Üniversitesi Sosyal Bilimler Dergisi, 22(Özel Say1), 43-56.

\footnotetext{
${ }^{1}$ Bu çalışma etik kurul izin belgesi gerektirmemektedir.

${ }^{2}$ Hakkari Üniversitesi İIBF Maliye Bölümü, burakokde@hakkari.edu.tr, ORCID: 0000-0002-0314-1293
} 


\title{
YUNUS EMRE
}

VE DÜNYA DiLI TÜRKÇE YILI

\section{The Economic Collapse and Tax Oppression of Anatolia in the Period of Yunus Emre}

\author{
Burak ÖKDE ${ }^{3}$
}

Submitted by: 01.11.2021

Accepted by: 28.12 .2021

Article Type: Research Article

\begin{abstract}
Yunus Emre is one of the respected poets and intellectuals that the Turkish World has raised. Despite the difficult conditions of the period in which he grew up, he determined a style based on the language of tolerance and peace in his poems. This style has made him a name that has been remembered and respected for centuries. Yunus's language is more appreciated, especially considering the period in which he lived. Anatolia in the 13th century has experienced a change that is rare in history. The first half of this century has been a period of abundance, prosperity and peace. The second half of the century in which Yunus lived was a period of wars, rebellions, looting and Mongol pressure, and there was no security of life and property. The aim of the study is to reveal the change in the economic and commercial life in Anatolia in the second half of the 13th century and the beginning of the 14th century, that is, in the period when Yunus lived. As a result of the study, it is revealed that there is a heavy tax burden on the people in Anatolia, misery and wars have replaced peace and prosperity, and the economic life has collapsed systematically. The new situation that emerged caused great migrations in Anatolia and an increase in the population of the border principalities in the western regions. If we consider that the principalities were surrounded by Mongolian pressure and occupation from the east, we can better understand the Turks' westward conquest and settlement policies. Yunus's approach of love and tolerance makes him more valuable at a time when there is no state authority, poverty, famine, war, plunder and rebellion.
\end{abstract}

Keywords: Yunus Emre, Anatolian Seljuk State, Tax, Tax Pressure

\footnotetext{
${ }^{3}$ Hakkari University Faculty of Economics and Administrative Sciences Department of Public Finance, burakokde@hakkari.edu.tr, ORCID: 00000002-0314-1293
} 


\section{Giriş}

Yunus Emre, Türk tarihi açısından önem arz eden ve Türk tarihinin dönüm noktası sayılabilecek 13. yüzyılın ikinci yarısı ile 14. yüzyılın ilk çeyreğinde yaşamıştır. Hoşgörü ve sevgi merkezli yaşam felsefesi ile tarihte yer alan Yunus'un, günümüze kadar ulaşmış olmasının bir nedeni de yaşadığg dönemde mevcut olan zor şartlar, savaşlar, kıtlıklar ve yoksulluk olabilir. İçinde yaşadığı döneme tezat olabilecek şekilde hoşgörüden ve sevgiden bahseden Yunus, bu tezat durum sayesinde gönüllerde daha derin yer etmiş olabilir. Bu nedenle Yunus'u anlamak için yaşadığı dönemdeki zorlukları iyi tahlil etmek gerekmektedir.

Anadolu, 10. ve 11. yüzyıldan itibaren Türk göçlerine sahne olmuştur. Türkler geldikleri yerlerin kültürünü ve iktisadi özelliklerini de birlikte getirmişlerdir. Genellikle tarım ve hayvancılıkla uğraşan Türkler, toplayıcılıkla da ilgilidirler. Yunus Emre de toplamış olduğu yabani meyveleri, Hacı Bektaş-i Veli ile buğday karşıllğında takas etmek istemiştir (Baykara, 2004, s. 279).

1204 yllında meydana gelen 4. Haçlı Seferi, İstanbul'un işgaline neden olmuştur. Bu işgal neticesinde İstanbul yıllarca yağmaya uğradığı gibi, Anadolu’da da siyasal yapıda değişimler gözlemlenmiştir. Bizans yönetiminin zayıflaması ile, Moğol istilasının da başlamadığı dönemde, yani 13. yüzyılın başlarında ortaya çıkan bu siyasi boşluktan Anadolu Selçuklu Devleti (Selçuklular) faydalanmış ve Anadolu'da siyasi ve iktisadi ağırlığını ortaya koyarak mevcut boşluğu doldurmuştur. Bu durumun daha sonraki yıllarda ortaya çıkacak iktisadi ve siyasi etkileri olacaktır (Aksoy, 2019, s. 192).

13. yüzyıl tarih sahnesinde ilginç olayların yaşandığı bir asır olarak dikkat çekmektedir. Türkler açısından da müstesna bir asır olarak değerlendirilmektedir. Türkler Anadolu'da bu yüzyılın başında güçlü bir ilerleme sergiledikleri gibi yüzyılın ikinci yarısında bir çöküş dönemine girmişlerdir (Turan, 1996, s. 539). Yabancı kaynaklar da 13. yüzyılda Selçuklular’ın refah ve zenginliğinden sıkça bahsetmektedirler. Şüphesiz bu refahın kaynağı bilinçli bir şekilde uygulanan devlet politikalarıdır (Bedirhan, 2015, s. 28).

Bu politikalardan en önemlisi Selçuklular'ın izlemiş olduğu iskân politikasıdır. Nitekim Anadolu Rum, Ermeni ve Arap kökenli yerleşiklerin bulunduğu bir yerdir. Ancak, bu unsurlar zorunlu nedenler olmadıkça kendi bölgelerinin dışına çıkmaz ve farklı bölgelerle sınırlı olarak ticaret yaparlardı. 12. yüzyıldan sonra Anadolu’ya yayılan Türkler farklı bölgelerde ziraat ve hayvancılıkla uğraşmış ve farklı bölgelerdeki Türkler ile ticaret yapmışlardır. Türkler arasında mevcut olan bu bağ ticaretin hızlanmasını ve Anadolu’ya yayılımın artmasına neden olmuştur (Aksoy, 2019, s. 196).

13. yüzyılın ikinci yarısı ile 14. yüzyılın ilk yıllarında ise mevcut durum tersine dönmüştür. Bu dönemde her türlü olumsuzluk yaşanmıştır. İç karışıklıklar, Türkmen isyanları, halka uygulanan ağır vergiler, kuraklık ve yağma hareketleri gibi olayların yanında Moğol saldırıları da durumu iyice kötüleștirmiştir (Günay ve Horata, 1994, s. 8).

Yunus Emre de bolluğun ve refahın değil, çöküş döneminin başladığı ve Babailer İsyanının gerçekleştiği 1240 yıllarında dünyaya gelmiştir. Akabinde 1243 yılında Moğollar ile yaşanan Kösedağ Savaşı'nın kaybedilmesi, Selçuklular'ın Anadolu'da hakimiyetini kaybetmesine ve Moğol idaresinin gölgesinde var olan bir devlet hâline gelmesine neden olmuştur. Daha sonra meydana gelen iç çatışmalar ve Moğol baskıları neticesinde Anadolu'da yaşanan çöküş dönemi, İlhanlı Devleti'nin (İlhanlılar) yıkılacağı 1335 yılına kadar devam edecektir (Yediyıldız, 1991, s. 24).

Böyle bir dönemde yaşayan Yunus'un geçimini nasıl sağladığı net değildir. Yerleşik olarak ziraat ile uğraşmış da olabilir, göçebe olarak hayvancllık da yapmış olabilir. Çöküş ve yokluk döneminde ayrım yapma firsatı bulamadan çalışmış da olabilir. Yunus'un hoşgörü yaklaşımı bu şartlarda şekillenmiş, ayrıca farklı etnik ve dini kimliklerin de yoğun olduğu Anadolu'da eşitlik söylemi bu unsurlardan da etkilenmiş olabilir (Göçer, 2020, s. 826). 
Selçuklular'ın çöktüğ̈̈, beyliklerin ortaya çıktığı bir dönemde yaşayan Yunus, şüphesiz bu ortamdan etkilenmiştir. Siyasi belirsizlik ve iç çekişmeler ile beraber Moğol saldırılarının sürdüğü bu ortamda halkın herhangi bir can ve mal güvenliği de bulunmuyordu. Böyle bir ortamda Yunus, sabrı, metaneti, hoşgörülü ve sabırlı olmayı telkin etmiştir. Şiirlerinin yaşadığı çevreye ve daha uzaklara ulaşarak Türkmen boylarına umut verdiği ve manen insanları desteklediği sonucu çıkarılabilir (Arayancan, 2021, s. 205).

Ahi örgütüyle göçebe Türkmenler'in birbirine destek olması da bu yokluk, savaş ve kaos ortamıla açıklanabilir. Yunus Emre'nin babasının da muhtemelen Babailer İsyanına katılan ahiler ile hareket ettiği düşünülebilir. Bu durumda Yunus'un, sevgi, sükûnet ve barış ortamına olan özlemi ve söylemi daha iyi anlaşılabilir. Yunus, hiç kimseyi sevgi ve hoşgörü söyleminin dışında bırakmadan, tüm Anadolu unsurlarını kucaklamaktadır. Çünkü bu yıkım ve çatışma ortamının tüm halklar üzerinde olan olumsuz etkilerinin farkındadır (Göçer, 2020, s. 827).

\section{Türkiye Selçuklu Devletinin İktisadi Gelişimi}

Malazgirt Zaferinden (1071) sonra Türklerin Anadolu'ya yayılması ve yerleşmesi hız kazanmıştır. Türkler bu tarihten sonra gerçekleştirdikleri iskan politikaları ve zenginleştirdikleri ticari hayatın ardından bir refah ve huzur dönemi yaşamışlardır. Bunu yaparken de yerel unsurlarla kaynaşma yolunu seçmiş, savaş ve yağma yöntemlerini kullanmamışlardır.

Selçuklular'ın Anadolu'ya entegre olmasının, ekonomik ve kültürel faaliyetlerinin takip edilmesinin en çarpıcı kanıtı olarak kervansaraylar ve dini yapılar gösterilmektedir (Peacock, 2014, s. 278). Bu durum Selçuklular’ın Anadolu'yu bayındır ve güvenli bir bölge hâline getirmelerinin bir sonucu olarak değerlendirilmektedir. Bu ortam sayesinde ülke çapında üretim ve ticaret hayatı zenginleşmiş, yolların güvenli hâle getirilmesi ve kervansaraylar yapılması sayesinde yeni ticaret yolları ortaya çımış ve Anadolu'da birçok kent zenginleşmiştir.

Selçuklular döneminde önem kazanan ticaret hayatının bir sonucu olarak kuzey-güney doğrultusunda yer alan şehirler, yeni ticaret yolları arasında yer almışlardır. Bağdat-Halep-Malatya-Sivas-Trabzon doğrultusunda yer alan hattın orta noktasında yer alan Sivas, ticari bir merkez hâline gelmiştir (Darendeli ve Binan, 2021, s. 147). Bir diğer gelişen şehir ise doğu-batı aksında yer alan Erzincan'dır. Erzincan da Sivas ve Konya gibi ticari hayatın zenginleştiği illerdendir (Yuvalı, 1990, s. 597). Aynı şekilde güneyde de liman kenti olan Ayas, ithalatın ve ihracatın yaygın olarak gerçekleştiği bir kent konumundadır (Bedirhan, 2016, s. 20).

Ülkenin başkenti Konya ise tüm bu ticari faaliyetlerin merkezindedir. Kuzeyden güneye ve doğudan batıya ülkedeki ticaret yollarının coğrafi konumu gereği kesişim noktasında olan Konya, başkent olmasının yanında ticaret merkezi olarak da dikkat çekmektedir (Aksoy, 2019, s. 211).

Selçuklular, canlı ticaret hayatı ve güçlü mali yapı ile birlikte kültürel ve bilimsel alanlarda da çalışmaların yaygınlaşmasına zemin hazırlamıştır. Bu konuda özellikle islami alanlarda yapılan çalışmalarda Ahlat dikkat çekmektedir. Bu çalışmalarından ve çok sayıda din aliminin yetişmesinden dolayı Ahlat 'kubbetül İslam' olarak adlandırılmıştır. Aynı zamanda çok sayıda mimari eserin ortaya koyulmasında Ahlat önemli bir paya sahip olmuştur (Bedirhan, 2015, s. 41).

Anadolu'da yapılan yatırımlar ile birlikte huzur ve güven ortamının sağlanması iktisadi ve sosyal hayatı geliştirmiştir. Bununla birlikte ticaret ve ihracat hayatının zenginleşmesi için, kara komşularından bağımsız olarak deniz ticaretinin de gelişmesi gerekmektedir. Çünkü o yıllarda sıklıkla karşılaşılan kara komşuları ile çıkan çatışmalar ve savaşlar gümrüklerin kapanmasına neden olmaktadır. Bu nedenle ticarette ve üretimde istikrarın sağlanması için sahil kentleri de fethedilmiştir. 
Kuzeyde ve güneyde yer alan liman kentlerinin ele geçirilmesi ile Selçuklular, ticarette denizlerden önemli oranda istifade etmiştir. Gemilerle yabancı ülkelerden gelen ürünler Antalya'ya indirildikten sonra, Anadolu'ya Kayseri, Konya, Sivas ve Erzincan gibi iller üzerinden yayılma imkânı bulmuştur (Bedirhan, 2016, s. 24).

Bu dönemde gerek ticaret hayatının gelişmesi gerek göç ile gelen Türkmenlerin iskân edilmesi için, ülkede barış ve huzurun tesis edilmesi gerekliliği ortaya çıkmıştır. Bu amaçla ülkede yer alan diğer etnik ve dinî unsurlarla çatışma değil, uzlaşı ve birlikte çalışma ortamından istifade edilmiştir (Aksoy, 2019, s. 193).

Huzurun ve barışın tesis edilmesi, canlı ticaret hayatı ve düşük vergiler sadece Selçuklu hakimiyetinde yaşayanları değil, komşu ülkeleri de cezbetmiştir. 12. yüzyılın sonlarına doğru Bizans ile komşuluk ilişkilerinin yaygınlaşması, Bizans'ın uygulamış olduğu yüksek vergiler ve adalet anlayışının zedelenmesi, birçok Bizans köylüsünün Selçuklular hakimiyetindeki köylere yerleşmesine neden olmuştur. Bu durum iktisadi olduğu kadar, kültürel etkileşimin artmasına da neden olmuştur. Bu şekilde gerçekleşen göçlerin en önemli sebeplerinden biri de Selçuklular'ın kendisine bağlanan köylülerden vergi almayacağını belirtmiş olmasıdır (Demirkent, 2000, s. 153).

Ticaret hayatında yaşanan bu gelişmelerin etkileri devletin vergi gelirlerinde de görülmektedir. Artan ticaret ve üretim sonucunda devletin gelirleri Moğol işgaline kadar artmıştır. Moğol işgalinden önce Anadolu'dan 15 milyon, Doğu Anadolu ve Musul'dan 10 milyon, Ahlat'tan ise 2 milyon Dinar vergi toplanmaktaydı. İşgal ve yağma hareketinin başlamasından sonra ise Anadolu'dan 3,3 milyon, Doğu Anadolu ve Musul'dan 1,9 milyon, Ahlat'tan ise 390 bin Dinar vergi toplanabilmiştir (Turan, 2003c, s. 371). Bir başka kaynakta ise 13. yüzyılda Avrupa ile kıyaslanınca Selçuklular'ın vergi gelirleri 27 milyon altın iken, Fransa 3 milyon, İngiltere ise 4 milyon altın vergi gelirine sahipti (Turan, 1993b, s. 361). Moğol işgali ile Anadolu'da yaşanan gerilemenin mali boyutu açıkça görülmektedir.

$\mathrm{Bu}$ tablonun ortaya koyduğu bir diğer sonuca göre, vergilerin sadece bir devletin gelir kaynağı olarak yorumlanmaması gerektiği anlaşılmaktadır. Vergiler, aynı zamanda devletin ülkedeki hakimiyetini, otoritesini ve sahip olduğu iktisadi gücü de göstermektedir. Güçlü bir vergi sistemi bir devletin varlığını sürdürebilmesi için de gereklidir (Demir, 2018, s. 80). Bir devletin ülkedeki hakimiyeti kaybetmesi ile ekonomik faaliyetler zarar göreceği gibi, devletin mali durumu da şüphesiz olumsuz etkilenmektedir.

Selçuklular’n siyasi ve idari yapısı incelendiği zaman ise görülmektedir ki, dönemindeki diğer devletlere benzer şekilde idari ve mali yapılanmasının başında divan yönetimi bulunmaktadır. Divan örgütlenmesinin başında büyük divan yer almaktadır. Alt kademedeki divanlar ise sultanın dış ülkelerle ilişkilerinin ve yazışmalarının görüşüldüğg̈ Divanül İnşa, ordu ile alakalı mevzuların görüşüldüğü Divanül Arz ve mali işlerin görüşüldüğü Divanı İstifa olarak adlandırılmaktadır (Küçük, 2013, s. 239). Böyle bir yapılanma mevcut olmasına rağmen, kayıtların net olmaması ilginçtir. Nitekim, Selçuklular’ın idaresi altında farklı din ve milletlerden insanlar yaşamakta idi. Bu yapı nedeniyle vergi sisteminin tam olarak netleşmediği düşünülebilir.

Farklı din ve milletlerin bir arada yaşaması dolayısıyla, zenginleşen ticaret hayatına karşılık, Selçuklular'da devletin hangi vergileri aldığı net olmamakla birlikte, toplanan vergilerin sadece şer’i vergiler olmadığı da bilinmektedir (Ağdemir, 2021, s. 640). Vergiler üzerindeki belirsizlik, Osmanlı Devleti öncesi Türk devletlerinde karşılaşllan genel bir sorundur. Eğer vergileme ile ilgili detaylı bilgiler olsaydı, buradan yola çıkarak nasıl bir idare ve üretim yapısı olduğu konusu da daha iyi anlaşılabilirdi (Polat, 2010, s. 49). Vergilerin toplanmasında ise zamanla yöntem değişikliğine gidildiği görülmektedir.

Bazı tarihi belgelere göre bir ile atanan komutanın aynı zamanda o ilin vergilerini toplamada yetkili kılındığı görülmektedir. Bu durum il valilerinin aynı zamanda ikta sahibi olduğuna da işaret etmektedir (Köymen, 1964, s. 336). 
Ancak, kuruluş zamanlarında görülen illerin ikta sistemiyle en yüksek rütbeli komutanlara tahsis edilmesinin birtakım sakıncaları bulunuyordu. Özellikle merkezi sistemin zayıflaması ve ikta sahiplerinin güç kazanma ihtimali, daha sonraki dönemlerde bu uygulamadan vazgeçilmesine neden olmuştur. Yeni uygulama ile, bir ilin başındaki komutan, bölgedeki vergiler üzerinde hak ve sorumluluk sahibi olmadan sadece kendisine görevi karşıllı̆ında verilen maaş ile gelir sahibi olmaya başlamıştır. Bu durum şüphesiz devletin daha merkeziyetçi bir anlayışa sahip olduğunu göstermektedir (Göksu, 2009, s. 146). İkta sisteminin bir diğer olumsuz tarafı ise, merkezi otoritenin zayıflaması durumunda, kontrolsüzlük sonucunda sistemin halkı ezen bir görüntü vermesine neden olmasıdır (Demir, 2018, s. 83).

Selçuklularda iktâ sistemi, siyasi istikrarsızlıklar ve mücadeleler dolayısıyla yavaş yavaş sarsılmış ve İlhanlılar'ın Anadolu'yu tamamen işgal altına almaları ile birlikte Selçuklu ordusu fiilen ortadan kalkmış ve Selçuklu iktâ sistemi de yıkılmıştır (Aktan, 1986, s. 172).

İkta sistemi daha sonraki dönemlerde siyasi, iktisadi ve sosyal huzur ortamının bozulmasıyla etkinliğini iyice kaybetmiş, Moğol saldırıları ve İlhanlı işgali ile yok olan Selçuklu ordusu ile birlikte tarihe karışmıştır. Ülkeye yapılan işgal hareketleri ve savaşlar, vergilerin artırılmasına neden olmuştur. Bu durumun bir sonucu olarak isyan hareketleri görülmektedir.

$\mathrm{Bu}$ isyanların en bilinenlerinden Babailer isyanıyla birlikte Selçuklular üzerinde olumsuz etkiler meydana getiren Oğuz isyanı da Türkmenlerin çıkarmış olduğu isyanlardır. Bu isyanlara baktığımız zaman halk üzerinde olumsuz etkileri olan vergilerin etkileri dikkat çekicidir (Ağdemir, 2021, s. 644).

Selçuklular 1237-1246 tarihleri arasında siyasi ve iktisadi olarak zayıflaması sonucunda ortaya çıan isyanlar ile birlikte gücünü iyice kaybetmiştir. Moğol saldırılarına karşı da savunmasız kalan devlet yok olmuş ve 1330’lu yıllara kadar Anadolu’yu Moğol valileri yönetmiştir (Soltani ve Rezaei, 2019, s. 160).

13. yüzyılın ilk yarısında sultanların büyük başarısı ile devlet büyük bir yükseliş göstermiştir. İç çekişmelerle birlikte zayıflayan bu yükseliş, Moğollar nedeniyle yerini bir yıkıntıya bırakmıştır. Bu yok oluş sonraki yüzyıllarda Anadolu'nun batısında yerini yeni gelişmelere ve ilerlemelere bıraksa da Anadolu'nun doğusu bir daha eski canlı ve zengin günlerine kavuşamamıştır (Yuvalı, 1990, s. 589, 590). Anadolu'da halkın üstünde İlhanlılar'ın baskıları yeterince zorluk yaşatırken, kıtlık ve kuraklıklar ile sıkıntılar dayanılmaz boyutlara ulaşmıştır (Yuvalı, 1990, s. 586).

Selçuklular’nn ekonomiye ve ticarete vermiş olduğu önem, döneminin en ayırt edici özelliklerinden biridir. Ticarette vergi indirimleri, sermaye sahiplerinin gerekli görülen yerlere iskanı, ahi teşkilatı, ticaret güzergahlarının oluşturulması ve güvenceye alınması gibi uygulamalar ticarete verilen önemi göstermektedir (Bedirhan, 2015, s. 41).

Ticaret hayatının önemli bir parçası olan ahiler, Anadolu'da yerleşik hayata yeni geçen unsurları içinde barındıran bir topluluk hüviyetindedir. Yerleşik hayata tam olarak adapte olamayan Türkmenler, kent çevrelerinde eski alışkınlıklarına devam etmişlerdir. Moğol saldııları başladığı zaman tekrar göçebe yaşam tarzına dönüldügü bilinmektedir. Bununla birlikte göçebe yaşam tarzını benimseyen ahilerin Moğol istilasına direniş gösterdikleri de değerlendirilmektedir (Polat, 2010, s. 55). 


\section{Kösedağ Savaşı Sonrası Çöküş Dönemi}

Anadolu'nun yaşamış olduğu bolluk, bereket ve huzur dönemi kalıcı olmamıştır. Yunus Emre'nin doğduğu yıllardan ölümüne kadar Anadolu kıtlıklar, isyanlar, işgaller ve yağmalarla yok edilmiştir.

13. yüzyılın ortalarından itibaren Moğol saldırıları devlet otoritesini zayıflatmış ve halk ağır vergiler ödemek durumunda kalmıştır. Can ve mal güvenliğinden endişe eden halk, sınır köylerine doğru yoğun göç hareketleri başlatmış ve Bizans Devleti sınırlarında bir nüfus artışı meydana gelmiştir (Akın, 1968, s. 4).

Özellikle Moğol saldırıları ve işgali başladıktan sonra halk artık eski huzur ve refah dönemini bir daha görememiştir. Moğollar ile olan savaşı kaybeden Selçuklular, bundan sonraki dönemde giderek artan istek ve vergileri karşılayabilmek için daha çok vergi toplamak durumunda kalmıştır. Bunun yanında Moğollar bazı yerlere kendi askerlerini ve yöneticilerini görevlendirerek buraları bizzat yönetmiş ve vergilendirmiştir.

Moğolların topladığı verginin değerini anlayabilmek için şöyle bir karşılaştırma yapılabilir. Moğol devletinde "Baliş" yaygın bir para birimiydi. İlhanlılar'da da Moğol Devleti'nde olduğu kadar olmasa da bu para birimi kullanılmıştır. Bir Altın Baliş 200 kağıt paraya, bir dinar ise bir gümüşe denk gelmekteydi (Kopar, 2008, s. 126).

Moğol Devleti'nin mali yapısı üç temel vergi unsuruna dayanmaktaydı. Bu vergilerden ilki toprak sahiplerinden alınmaktaydı. İkinci vergi türü konar-göçer yapıda bulunanlardan alınan hayvan vergisi, üçüncü vergi ise şehirlilerden ve tacirlerden alınan vergiydi (Validi, 1931, s. 18).

Vergiler, önceden türleri ve oranları belirlenmiş olarak tahsil edilirdi. Bununla birlikte vergilerin ödeme zamanı da önceden belirlenmiştir. Vergi konusunda Moğollar kaideleri belirlenmiş olan verginin tahsilini kısa zamanda gerçekleştirmiş, ihmali olan görevlileri ise cezalandırmıştır (Köymen, 1964, s. 357).

Selçuklular'da ise vergilendirme dört temel kaynağa ayrılmıştır. Özellikle Moğol saldırıları sonucunda alınan vergilerde Moğolların masrafları ve istedikleri haraçlar için de kalem ayrılmıştır. Cizye olarak alındığı düşünülen vergi ile birlikte, Anadolu'da konaklayan Moğol ordusu masrafları için de bir vergi toplanmaktaydı. Posta vergisi olarak toplanan diğer verginin de Moğol elçilerinin, kuryelerinin gidiş ve dönüş masraflarına harcandığı tahmin edilmektedir. Bu vergilerin dışında bir de sınır boylarında yerleşik olan beylerden alınan uç vergisi mevcuttu (Aksarayi, 2000, s. 68).

1243 Kösedağ Savaşı'nın kaybedilmesi ile birlikte Selçuklular'ın Moğollar'a yıllık vergi, köleler, yük ve besi hayvanları gibi tazminat ödemesi konusunda anlaşıldı. Bununla birlikte Moğolların da Selçuklu iç işlerine karışmaması konusunda karara varıldı. Ayrıca, Moğol elçilerinin yol masrafları da Selçuklular tarafından karşılanacaktı (Erdem, 1995, s.95).

1258 yllında İlhanlı'lara Rum diyarından (Anadolu) ödenecek olan vergiler; yirmi tümen (1 tümen 10 bin dinar), kumaşlar, altın işlemeli eşyalar ve bin tane yük taşıma hayvanı şeklindedir (Aksarayi, 2000, s. 46). Yapılan anlaşma Selçuklular tarafından karşılanamayacak veya devleti zor duruma sokacak nitelikte değildi. Bununla birlikte Moğol istekleri ve vergileri gün geçtikçe artmış ve yük hâline gelmeye başlamıştır (Yuvalı, 1990, s. 582).

Bu durum 1276 yılına kadar vergilerin sürekli artışı ile devam etti. Selçuklular'ın iktisadi ve idari yapılanması yok olma noktasına kadar geldi. 1256'dan itibaren İlhanlı Devleti'nin kurulması ile de süreç kötüleşerek devam etti. Selçuklular üzerinde vergi yükü o kadar artmıştı ki, İlhanlı'lara ödenecek vergiler için kaynak bulunamadığından, devlet yönetimindeki idareciler, maaşlarından bu yükü karşılamaya çalışmışlardır. Ağır vergilerden dolayı isyan eden Türkmenlere beylik unvanı verilerek sorun çözülmeye çalışllmıştır (Kopar, 2008, s. 129).

Ortaya çıkan güvensizlik ortamı ticaret hayatını da olumsuz etkilemiştir. Ülke içinden ve dışından gelen kervanlar sürekli yağmalanır hâle gelmiştir. Kıymetli madenler yağmalandığından dolayı, bu durum sanayi alanında üretimin de yok olmasına neden olmuştur (Kopar, 2008, s. 134). 
İlhanlı Devleti’nin kurulması ile Anadolu'nun durumu farklı bir boyuta ulaşmış durumdadır. Ülkenin ekonomisi ve idari yapısı çökmüş, ülke işgal altında kalmış, ülkede bulunan İlhanlı askerlerinin masraflarını karşılamakla yükümlü olan devlet bu yükün altında ezilmiştir (Yuvalı, 1990, s. 584).

Şekil 1'de 13. yüzyılda İlhanlılar'ın vergi gelirleri gösterilmektedir. Vergi gelirleri “tümen” cinsinden gösterilmiş olmakla birlikte, 1 tümen 10 bin dinara karşıllk gelmektedir. Dolayısıyla Anadolu'dan elde edilen gelir 126 tümen yani 12 milyon 600 bin dinar etmektedir.

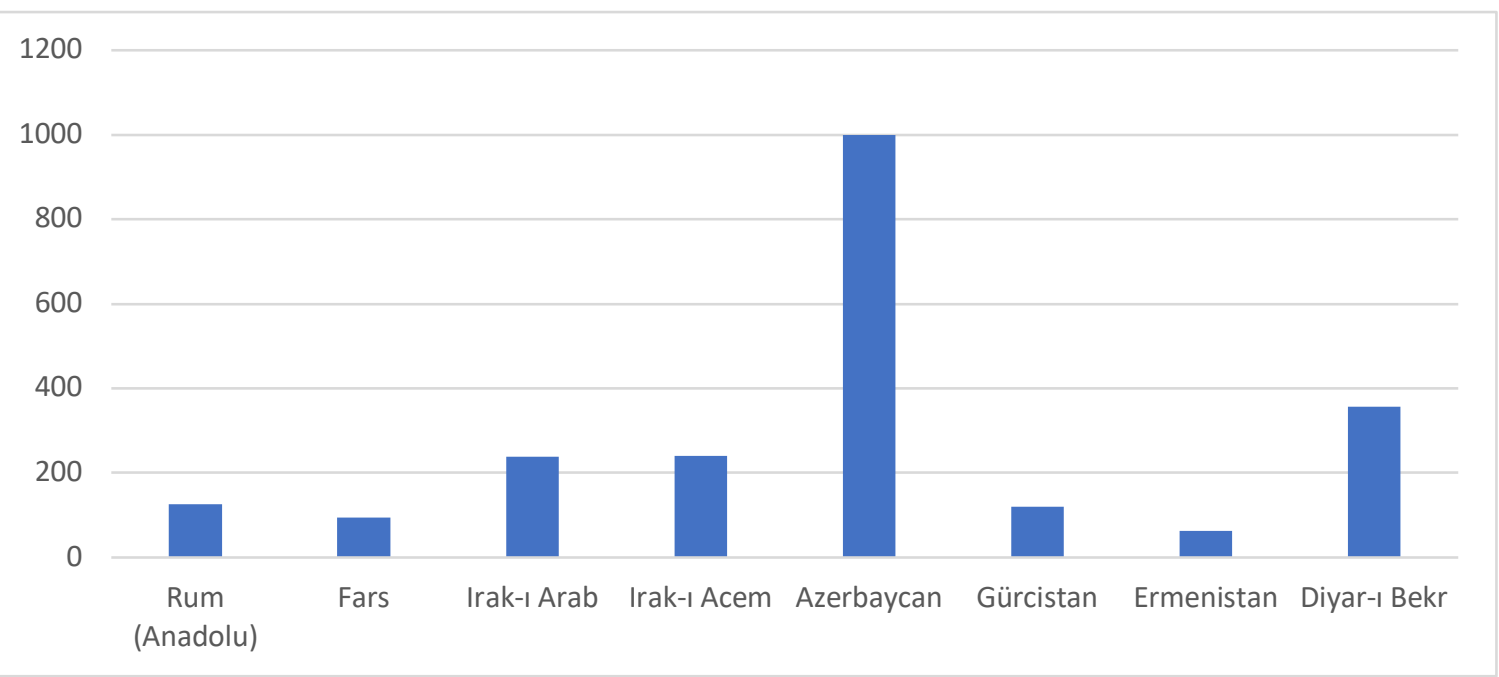

Şekil 1. İlhanlı vergi tahsilatı (Tümen, 10.000 dinar=1 Tümen) Kaynak: Güneş, 2021, s. 98.

Turan'ın (2003c: 371) verdiği bilgilerde Selçuklular Anadolu'dan Moğol istilası öncesinde 15 milyon dinar vergi toplamaktadır. Dolayısıyla Şekil 1'deki veriler göz önüne alındığında 15 milyon dinar verginin 12 milyon 600 bini İlhanlılara vergi olarak ödenmektedir. Bu tutarlara, Anadolu’ya yerleşik olan Moğol askerlerinin masrafları ve keyfi haraçlar dahil değildir.

Selçuklular'ın hakimiyetini kaybetmesi ile Anadolu'da ticaretin kontrolünü de Moğollar sağlamaya başlamıştır. İlhanlılar’ın doğudaki Memlüklüler ile olan rekabeti, batıda ticari etkileşim sağladığı hristiyan ve yahudi milletlerle ilişkilerini geliştirmesine neden olmuştur (Kopar, 2008, s. 127).

$\mathrm{Bu}$ durum aynı zamanda 13. yüzyılda görülen siyasi bloklaşmanın da bir sonucudur. İlhanlı ve Memlüklü Devletleri dönemin iki süper gücü olarak tarih sahnesinde yer almıştır. İlhanlı’lar Fars, Kafkas ve Anadolu üzerinde yaklaşık 100 yıl boyunca tek egemen güç olmuşlardır (Haykıran, 2019, s. 161).

Böyle bir durumda Selçuklular elde etmiş olduğu limanlar nedeniyle bir deniz gücü olmaya çalışmışsa da esas unsurları kara kuvvetlerindeydi. Bu nedenle ticareti yönlendirebilmek ve etkin bir vergileme sağlayabilmek için kara kuvvetlerinin güçlü olması gerekmekteydi (Aksoy, 2019, s. 211). Ancak, ortada bir mali güç kalmadığı gibi, düzenli bir ordunun varlığından söz etmek de artık mümkün değildi.

İlhanlılar'ın Anadolu’ya olan etkileri galip bir devletin mağlup devletten aldığı savaş tazminatı ve vergiler ile sınırlı değildi. İlhanlılar Anadolu'nun adeta varını yoğunu istediler, her zaman daha fazlası için geldiler. Artık vergi olarak alınacak bir şey kalmayınca da geri kalanları adeta yağmalayıp götürdüler. Anadolu'ya görevlendirilen İlhanlı görevlileri bir altın vergisi olan yerden on altın almış, üç bin altınlık yerden elli bin altın vergiyi tahsil etmiştir. Önüne gelene keyfi para cezaları uygulamış, devlet adamlarından rastgele paralar toplamıştır (Turan, 2003c, s. 632). 
Özellikle 1256'dan sonra Moğol orduları Anadolu’ya tamamen yerleşmiştir. Yıllık ödenen vergi ve hediye yükünden bunalan Selçuklular, bu ordunun masrafına da katlanmak zorunda kalmışlardır. Zaman zaman farklı seferler için ordu geri çağrılmışsa da Anadolu artık sürekli Moğol askerleri ile yaşamak zorunda kalmıştır (Erdem, 2003, s. 51).

İlhanlılar istediği vergilerde sürekli artışa gitmiştir. Bu durum öyle bir noktaya gelmiştir ki, İlhanlı Veziri Kazvini "gerekli olmadığı hâlde" vergileri artırmış, hatta kişi başına "can” vergisi koyup tahsil etmeye başlamıştır. Bu durum artık insanların isyan etmesine neden olmuştur (Aksarayi, 2000, s. 117).

1285 yılında ise İlhanlı şehzadeleri Anadolu'ya gelerek Erzincan'da kışı geçirmek için konaklamışlardır. Erzincan Beyi, onların istek ve ihtiyaçlarını karşılamakta zorlanmıştır. Şehzadelerin istekleri o kadar büyüktür ki, elli yıllık hazine vergisi, eldeki paralar ve mallar şehzadeler için harcanmıştır. Söylenilenlere göre Moğolların isteklerini karşılamak için eldeki avuçtaki her şey harcanmış, halkta yakacak bir mum bile kalmamıştır. Yapılan harcamaların kayıtlarını tutmak bile bir günden fazla sürmüştür (Aksarayi, 2000, s. 115). Aksarayi vergi toplayan mültezimlerden bahsederken "her biri Ebu Leheb’e hizmetçi ve köle olmaya hazır" ifadelerini kullanmaktadır (Aksarayi, 2000, s. 208-209). Bu durum Anadolu’nun mahkûm kaldığı baskı, eziyet ve zulmü ifade eder niteliktedir.

Moğol ordusunun yapmış olduğu tahribat yanında, halkın İlhanlı taraftarı yöneticilere karşı göstermiş olduğu isyanlar ticaret hayatını ve ziraat üretimini olumsuz etkilemiştir. Yüksek ve sürekli vergiler her tabakada hissedilerek, insanların günlük yaşamlarını çekilmez hâle getirmiştir (Kopar, 2008, s. 135).

İlhanlılar’ın kurmuş olduğu yağma düzeni sürekli etkisini arttırır niteliktedir. Bu dönemde kontrolü elden kaybetmemek için Anadolu'da Moğol birliklerinin sayısında da artışlar yaşanmıştır. Buna bağlı olarak kontrol ettikleri bölgedeki vergileri de sürekli artırmışlardır. Selçuklular’ı adeta esir aldıkları gibi, bulundukları bölgelerin yöneticilerini de kendi aralarından atamışlardır (Akkuş ve Bağc1, 2018, s. 160). Bu durumda Selçuklular’nn bağımsızlığından veya hakimiyetinden bahsetmek mümkün değildir.

Aslında İlhanlılar'da mali yapı merkezi bir örgütlenmeye işaret etmektedir. Vergi memurlarının toplamış olduğu vergiler merkeze aktarılmaktadır. Devletin yapacağı harcamalar ise yine merkezi yönetim tarafından karşılanmaktadır (Haykıran, 2019, s. 162). Ancak, resmi olarak toplanan vergilerin dışında görevlendirilmiş olan vali ve komutanlar, kendi menfaatleri ve çıarları doğrultusunda halktan ve idarecilerden haraçlar almış, yağmalar yapmışlardır. Bu nedenle Anadolu'daki mali yükü tam olarak belirlemek mümkün değildir.

Selçuklular'ın Anadolu'daki hakimiyeti zayıflayınca, İlhanlı'lar ellerindeki bölgelerin yönetimini görevlendirdiği valiler veya komutanlarca yürütmüşlerdir. Ancak, bu kişiler bir yönetim anlayışından ziyade, devletlerinin veya kendilerinin servet edinmeleri anlayışıyla hüküm sürmüşlerdir (Yuvalı, 1990, s. 592). Bu nedenlerden dolayı İlhanlı yönetiminde geçen sürelerde, Anadolu'da herhangi bir üretimden veya ticari hayatın varlığından söz etmek oldukça zordur (Yuvalı, 1990, s. 595).

Selçuklular ile ilgili nihai bir değerlendirme yapılacak olursa, 1277 yılından itibaren fiili bir devletin varlığından söz edilemeyeceği görülmektedir. Yaklaşık 50 yıllık bir süreç içinde ülkedeki savaş, yağma, soygun ülkenin tüm nizamını, ekonomisini ve hayat şartlarını yok etmiştir (Turan, 1993b, s. 506). Bu durumun etkileri o kadar derin olmuştur ki, İlhanlılar’a sadece Selçuklular değil, Osmanlı Devleti de kuruluşunun ilk elli yılında vergi ödemek durumunda kalmıştır (Küçük, 2013, s. 237).

Anadolu'da yaşanan bu gelişmeler ile birlikte, sınır boylarına yoğun bir Türkmen göçü yaşanmıştır. Bu göçler sonucunda sınırlarda küçük beylikler ortaya çıkmıştır. Bu küçük beylikler, Selçuklu veya İlhanlı Devletine bağlı sayılamayacak nitelikler taşımaktadır. Bu devletlerin genişleme sahası ise hristiyan topraklarına doğru olmuştur (Turan, 1948a: 558). Böylece Avrupa'nın ortalarına kadar sürecek olan Türk hakimiyetinin nedeni olarak, Moğol'ların Doğu'da yaşama şansı bırakmamış olması gösterilebilir. 


\section{Sonuç}

Yunus Emre, Türk Dünyası için zamanının yetiştirmiş olduğu en önemli şair, düşünce insanı ve mutasavvıflarından biri olarak görülmektedir. Yunus’un kullandığı sevgi dili, hoşgörü anlayışı, tevazusu ve barışa olan yaklaşımı, adını asırlar sonrasına taşıyan en önemli etkenler olarak karşımıza çıkmaktadır. Bu durumun bu kadar etkili olmasının ve Yunus'u unutulmaz yapmasının en önemli nedeni olarak Yunus'un içinde yaşadığı dönem gösterilebilir. Yunus, doğumundan 60-70 yıl önce doğmuş olsa söyledikleri bu kadar tesirli olmayabilirdi. Nitekim, o zaman Anadolu zenginliğin, huzurun, refahın ve farklı kimliklerin bir arada yaşayabildiği bir dönem olarak karşımıza çıkmaktadır. Oysa Yunus’un doğduğu yıllardan itibaren, Anadolu'da siyasi istikrar zayıflamaya başlamış, huzur ortamı bozulmuş, isyanlar ve çatışmalar artmış, ülke işgale uğramış, halkın can ve mal güvenliği ortadan kalkmış ve bir kaos ortamı Anadolu’ya hakim olmuştur.

Moğollar’a karşı yapılan Kösedağ Savaşı’nın kaybedilmesi ile, Anadolu artık işgal altına alınmıştır. Moğollar, Selçuklular’ı köşeye sıkıştırmış ve taleplerini reddedemez durumda olan Selçuklu idaresine yönelik vergileri ve talepleri sürekli artırmıştır. İlhanlı Devleti’nin kurulması ile Selçuklular artık müstemleke konumuna düşmüş, varlığını sadece bir formalite olarak sürdürmüştür. İlhanlılar, ülkenin tüm zenginliklerine el koymuş, ağır bir vergilendirme yoluna gitmiş, ayrıca görevlendirdiği valiler ve komutanlar ile de yağma ve talanda bulunmuştur. Bu durum ülkede can kayıplarına, yokluğa, sefalete, göçlere ve isyanlara neden olmuştur. Ülke elli yılda refahtan, huzurdan ve zenginlikten, yokluğa, savaşa ve esarete düşmüştür. Sadece bir yüzyıl içinde bu kadar keskin dönüşlerin olduğu bir dönem az görülebilir niteliktedir. Bu baskı ve zulüm ortamı insanların batıdaki uç beyliklerine göç etmesine neden olmuştur. Güçlenen beylikler doğu tarafı kapalı olduğundan, hareket edecek tek bir yöne, batıya doğru genişlemişlerdir.

Bu kadar savaşın, baskının, yokluğun, şiddetin, isyanların ve yağmaların olduğu, can güvenliğinin olmadığı bir ortamda yetişen Yunus'un sevgiyi, hoşgörüyü ve eşitliği savunması insanlar üzerinde daha büyük bir etkiye sahip olmasına neden olmuş olabilir. Türk tarihi açısından ilginç özellikler barındıran, bir o kadar da ders çıkarılması gereken olayların yaşandığı 13. ve 14. yüzyılların bırakmış olduğu en değerli miras ise Yunus Emre gibi kültür ve düşünce insanlarıdır. 


\section{Kaynakça}

Ağdemir, Z. (2021). Türkiye Selçuklu Devleti maliyesini İbn-İ Haldun ile anlamak: mali sosyolojik bir yaklaşım. Yönetim ve Ekonomi, 28(3), 631-655. doi: 10.18657/yonveek.909226.

Akın, H. (1968), Aydın Oğulları tarihi hakkında bir araştırma. Ankara: Ankara Üniversitesi Yayınları.

Akkuş, M. ve Bağcı, B. (2018). Hülâgû Han döneminde Anadolu'da görev yapan Moğol komutanları. USAD, 9, 150-171. Erişim adresi: https://dergipark.org.tr/tr/download/article-file/696752.

Aksarayi, K. M. (2000). Müsâmeretü'l-ahbâr. (M. Öztürk, Çev). Ankara: Türk Tarih Kurumu Yayınları.

Aksoy, F. (2019). XII.-XIII. yüzyıllarda Türkiye Selçuklularının Anadolu'nun Türk Yurdu olmasına etki eden iktisadi ve ticari faaliyetleri. Oğuz-Türkmen Araştırmaları Dergisi (OTAD), 3(1), 189-241. Erişim adresi: https://dergipark.org.tr/tr/download/article-file/774471.

Aktan, C. C. (1986). İktâ sistemi: İslam Devletlerinde ve Selçuklu İmparatorluğundaki uygulaması. Türk Dünyası Araştırmaları Vakfi, 44, 165-173. Erişim adresi: https://www.researchgate.net/publication/318672903_IKTA_SISTEMI_ISLAM_DEVLETLERINDE_ VE_SELCUKLU_IMPARATORLUGUNDAKI_UYGULAMASI.

Arayancan, A. A. (2021). Yunus Emre zamanında Anadolu'nun siyasi durumuna kısa bakış (1220-1318). Fetih ve Medeniyet, 1(2), 202-205. Erişim adresi: http://www.eskisehir.gov.tr/kurumlar/eskisehir.gov.tr/Dergi/dergi_2021_nisan.pdf.

Baykara, T. (2004). Türkiye Selçukluları sosyal ve ekonomik tarihi. İstanbul: IQ Kültür Sanat Yayınları.

Bedirhan, Y. (2015). Türkiye Selçukluları devrinde Anadolu'nun ticaret şehirleri. Tarih Okulu Dergisi (TOD), 24, 25-50. doi: 10.14225/Joh807.

Bedirhan, Y. (2016). Selçuklu Türkiyesi’nde ticaret yolları, limanlar ve pazar yerleri. Turkish Studies, 11(11), 13-28. Erişim adresi: https://app.trdizin.gov.tr/makale/TWpjeE1qUTBOQT09/selcuklu-turkiyesi-ndeticaret-yollari-limanlar-ve-pazar-yerleri.

Darendeli, T. ve Binan, C. Ş. (2021). Seljuks inherit to Anatolia; caravanserais. Athens Journal of Architecture, 7, 137-172. doi: 10.30958/aja.X-Y-Z.

Demir, H. İ. (2018). Türk vergi kültürüne etkisi açısından Türk vergi uygulamaları tarihine kısa bir bakış. Akademik Tarih ve Düşünce Dergisi, 5(18), 64-92. Erişim adresi: https://dergipark.org.tr/tr/download/article-file/618313.

Demirkent, I. (2003). Tatikios, Türk asıllı bir Bizans kumandanı. Belleten, 67(248), 93-110. Erişim adresi: https://dergipark.org.tr/en/download/article-file/1458366

Erdem, İ. (1995). Türkiye Selçuklu-İlhanlı ilişkileri (1258-1308). Basılmamış Doktora Tezii Ankara Üniversitesi Sosyal Bilimler Enstitüsü, Ankara.

Erdem, İ. (2003). Türkiye Selçuklu-İlhanlı iktisadi, ticari ilişkileri ve sonuçları. Tarih Araştırmaları Dergisi, 22(33), 49-67. doi: 10.1501/Tarar_0000000149.

Göçer, K. (2020). Yunus Emre aslında ne dedi? Turkish Studies, 15(2), 817-842. doi: 10.29228/TurkishStudies.41589.

Göksu, E. (2009). Türkiye Selçuklularında iktâ. Selçuk Üniversitesi Türkiyat Araştırmaları Dergisi, 26, 137-154. Erişim adresi: https://dergipark.org.tr/tr/download/article-file/257860.

Günay, U. ve Horata, O. (1994) Yunus Emre, risaletü’n nushiyye. Ankara: Türkiye Diyanet Vakfı Yayınları. 
Güneş, İ. (2021). Hamdullah Mustevfî̀ye göre 14. asırda ilhanlı vergi varidatı. Artuklu Kaime Uluslararası İktisadi ve İdari Araştırmalar Dergisi, 4(1), 88-109. Erişim adresi: https://dergipark.org.tr/tr/download/article-file/1621571.

Haykıran, K. R. (2019). İlhanlılar’ın son dönemlerinde mali durumları vergi işleyişi ve risale-î felâkiye. Üçüncü İktisat Tarihi Kongresi (s. 159-172) içinde. İzmir: İzmir Demokrasi Üniversitesi.

Kopar, M. (2008). Moğol istilası sonrası Anadolu Selçuklu Devletinde paranın seyri. Türk Dünyası Araştırmaları, $\quad 174, \quad 123-136 . \quad$ Erişim http://search.ebscohost.com/login.aspx?direct=true\&profile=ehost\&scope=site\&authtype=crawler\&jr $\mathrm{nl}=02550644 \& \mathrm{asa}=\mathrm{Y} \& A \mathrm{~N}=33361016 \& \mathrm{~h}=\mathrm{BN} 2 \mathrm{HEpHC}$ XFomK1YuFgHLkoHXHQzIwmTzLgjY5IOy XMkTOVYh\%2B1EDSGW0447zPsIYp5r0rOUx7EM4tGVW6xmSA\%3D\%3D\&crl=c.

Köymen, M. A. (1964). Selçuklu Devri Türk Tarihi araştırmaları. II. Tarih Araştırmaları Dergisi, 2(2), 303-380. doi: 10.1501/Tarar_0000000293.

Küçük, İ. (2013). Türk Devletlerinde mali yönetim- VIII.-XIII. yüzylllar arası. Muhasebe ve Finans Tarihi Araştırmaları Dergisi, 4, 223-245. Erişim adresi: https://dergipark.org.tr/tr/download/articlefile/319936.

Peacock, A.C.S. (2014). The Seljuk Sultanate of Rum and the Turkmen of the Byzantine frontier, 1206-1279. Al-Masaq, 26(3), 267-287. doi: 10.1080/09503110.2014.956476.

Polat, M. S. (2010). Osmanlı öncesi Türkiye'nin iktisat tarihine ilişkin sorunlar. SDÜ Fen Edebiyat Fakültesi Sosyal Bilimler Dergisi, 21, 43-58. Erişim adresi: https://dergipark.org.tr/tr/download/articlefile/117922.

Soltani, G. ve Rezaei, D. (2019). The effects of interactions within communal conditions in Iran and Anatolia with Il Khānids over 13th and 14th centuries. The Turkish Online Journal of Design, Art and Communication, 9(2), 159-177. doi: 10.7456/10902100/009.

Turan, O. (1948). Türkiye Selçuklularında toprak hukuku, miri topraklar ve hususi mülkiyet şekilleri. Belleten, 12(47), 549-574. Erişim adresi: https://belleten.gov.tr/tam-metin-pdf/896/tur.

Turan, O. (1993). Selçuklular zamanında Türkiye: siyaŝi tarih Alp Arslan'dan Osman Gazi'ye (1071-1318). İstanbul: Boğaziçi Yayınları.

Turan, O. (2003). Selçuklular tarihi ve Türk-İslam medeniyeti. İstanbul: Ötüken Yayınevi.

Turan, R. (1996). XIII. yüzyıl Anadolu buhranı ve ayakta kalan güçler. Erdem, 8(23), 529-540. Erişim adresi: https://dergipark.org.tr/tr/download/article-file/688900.

Validi, A. Z. (1931). Moğollar devrinde Anadolu'nun iktisadi vaziyeti. Türk Hukuk ve İktisat Tarihi Mecmuası, 1, 1-42. Erişim adresi: http://isamveri.org/pdfsbv/D00133/1931_1/1931_1_VALIDIAZ.pdf.

Yediyıldız, B. (1991). Yunus Emre dönemi Türk vakıfları. Vakıf Haftası Dergisi, 8, 23-28. Erişim adresi:http://acikerisim.fsm.edu.tr:8080/xmlui/bitstream/handle/11352/871/Yediy\%c4\%b1ld\%c4\%b1z. pdf? sequence $=1$ \&isAllowed $=y$.

Yuvalı, A. (1990). İlhanlıların Anadolu politikası ve Doğu Anadolu şehirlerinin vergi potansiyeli. XI. Türk Tarih Kongresi (s. 581-600) içinde. Ankara: Türk Tarih Kurumu. 


\section{Extended Abstract}

\section{Purpose}

The aim of this study is to reveal the difficulties of economic life in Anatolia during the time Yunus Emre lived. The aim is to determine the economic difficulties and high tax burden of the people in this period. By determining these conditions, it can be possible to better understand the concept of peace and tolerance that Yunus Emre mentioned in his poems during his lifetime. Because during the years Yunus lived in Anatolia, people of different religions and nationalities lived together. However, the wrong tax policies and pressures applied by the Anatolian Seljuk State caused rebellions within the country. The resulting rebellions weakened the central authority and the country became open to Mongolian attacks. With the loss of the war with the Mongols, the period of peace, tranquility and prosperity in the country came to an end. In the period when Yunus lived, there were heavy taxes, wars and poverty in Anatolia.

\section{Design and Methodology}

The study was carried out to understand the economic conditions of the period and the pressure of taxes on the people. It is aimed to investigate the events that took place seven hundred years ago. For this reason, two different methods were used within the scope of the research. These methods are qualitative research methods and quantitative research methods. The data obtained by using the numbers kept in the official records of the period and in the private books of the officials were evaluated within the scope of the quantitative research method. In order to support these data, qualitative research methods were used by making use of the texts that were not based on numerical values, but in which the people living in that period described the events. In this way, a harmony was achieved between the numerical data and the verbal data. It is very difficult to analyze the events that took place centuries ago. Considering the conditions of the period, the numerical data may not be sufficiently descriptive and detailed. It is also doubtful that these data have reached the present day completely. Likewise, non-numerical texts or memoirs may be written in a biased manner. Therefore, it is important to use these two data together. In this way, the research will be more consistent and the results will be easier to defend.

\section{Findings}

Many different sources were used to achieve the targeted results with the study. Among these sources are the official data and memoirs of the period, as well as current sources investigating the period. According to the results of the study, interesting results were obtained. In the period that is the subject of the study, it is seen that the political unity in the country has deteriorated. It has also been revealed that the existence of an institutional economic structure has collapsed. It is seen that heavy taxes were applied to the people living in Anatolia both by the Anatolian Seljuk State and by the Mongols. However, it is clear that as a result of the Mongol invasion, the Seljuk state actually disappeared and its authority was lost. The Mongols, on the other hand, took advantage of this situation and exploited all the resources of the country. The loss of political authority in the country has led to the emergence of an environment of chaos. Commercial life has come to the point of extinction and theft and looting have increased. As a result, intense migration movements were observed. These migration movements to the west of Anatolia caused political and social changes and the spread of Turks towards Europe.

\section{Research Limitations}

The limitations of the study stem from the period in which it was examined. Examining the events that took place centuries ago brings certain limitations. First of all, in this period, it is not possible to talk about the existence of effective institutions other than states in terms of record keeping. In addition, it is always possible for the records kept to disappear after many years. Another feature of the period is that records and libraries 
were burned by the Mongols. Apart from official institutions, the habit of keeping records individually is not common and it is known that people appointed by the states usually keep records. In addition, it is very possible for the written reports to take sides.

\section{Implications (Theoretical, Practical and Social)}

The study tried to reveal the economic situation and tax burden of Anatolia in the period when Yunus Emre lived, namely in the second half of the 13th century and the first quarter of the 14th century. During this period, there were two superpowers in the east. These states are the Mongolian states and the Mamluk state. In the west of Anatolia, there is the Byzantine state, which is constantly losing power. For this reason, researchers who want to do research on the period should investigate the policies developed by the Byzantine state regarding the emerging developments. Likewise, the relations of the Mamluk state with the Mongols and the effects of the Mongols' weakening and returning to Central Asia should be investigated. Revealing the effects of Byzantium and Mamluk states in researches about this period will enrich the study.

\section{Originality/Value}

There are many studies about Yunus Emre. However, these studies generally deal with the simplicity of the language used by Yunus in his poems, and his approach based on tolerance and love. Some studies, on the other hand, examine Yunus's contributions to Islam, based on religion. In studies dealing with the period in which Yunus lived, the war environment is generally mentioned. However, studies investigating how the wars affected the economy and what kind of tax burden the people living with Yunus were exposed to are rare. This study more strikingly shows Yunus's approach to peace and tolerance by dealing with the economic problems and tax burden of the period with wars and invasions.

Araştırmacı Katkısı: Burak ÖKDE (\%100). 